\title{
HEALTH PROTOCOLS AND HEALTHY LIFESTYLE SUGGESTIONS DURING COVID-19 IN INDONESIAN MINISTRY OF HEALTH'S KOMIK SEHAT: A PRAGMATIC APPROACH
}

\author{
Muhammad Gani Qodratul Ihsan, Njaju Jenny Malik Tomi Hardjatno \\ Faculty of Humanities, Universitas Indonesia \\ Depok, Indonesia \\ E-mail:muhammadgani25.05@gmail.com
}

Received: 2021-11-06

Accepted: 2021-12-01

\begin{abstract}
The government has enforced much socialization on health protocols and healthy lifestyle implementation during Covid-19, one of them through social media by presenting comics featuring utterances of characters. Accordingly, this research explains the utterances of comic characters that represent suggestions for implementing health protocols and healthy lifestyles during Covid-19. The objective of this study is to explain the strategy of delivering comic character messages that suggest health protocols and healthy lifestyles implementation. The data used in this paper are 38 Comics strips uploaded by the Indonesian Ministry of Health in their Instagram account entitled Komik Sehat. The results showed that of the 212 illocutionary speech acts, only $40.57 \%$ of utterances conveyed messages implementation of health protocols suggestions, and $6.6 \%$ of utterances conveyed messages implementation of healthy lifestyle suggestions. Therefore, the strategy of delivering messages on recommended health protocols and healthy lifestyles through stories in Healthy Comics is not effectively carried out by the Ministry of Health of the Republic of Indonesia.
\end{abstract}

Keywords: illocutionary act, directive speech act, health protocol, healthy lifestyle, comic, and Covid-19.

\section{Introduction}

Since the emergence of Covid-19 in Indonesia, the Indonesian Ministry of Health has become forefront in dealing with Covid-19. There are many ways to overcome the handling and socializing the importance of health protocols and healthy lifestyles implementation in the community, one of which is through comics uploaded through Instagram entitled Komik Sehat. In relation to language, comics are tools for delivering messages. In line with Eisner $(1985,8)$, comics use a series of images, symbols, and languages to deliver various kinds of ideas or thoughts. Cohn $(2012,92-93)$ also completes the argument that comics are social objects produced from two aspects, writing and drawing. Comics are also a common method to use visual language in a culture.

In the digital era, comics have changed from printed to digital, one of which can be found on Instagram. Zappavigna (2016) explains that Instagram is a social photography 'app' designed to run on smartphones where social media users can create visual and textual meanings, and other users can interact with those meanings. Based on data obtained by the 
British Institute We Are Social and Hootsuite, reported by Kemp (2021), Indonesia is one of the countries with social media users reach out 170 million active users in January 2021, which made Indonesian user data in Instagram occupy the third-highest position with a percentage of $86.6 \%$. Meanwhile, the first and second positions are YouTube $(983.8 \%)$ and WhatsApp (87.7\%). Based on this condition, the Indonesian Ministry of Health certainly sees an opportunity to deliver important information through the socialization of Komik Sehat on Instagram.

Kearns and Kearns $(2020,139)$ state comics as a familiar entertainment media can be enjoyed by various demographics of audiences and ready to share on social media for efficient mass information socialization. The Indonesian Ministry of Health performed this condition in delivering mass information regarding the prevention of Covid-19 in Indonesia through Komik Sehat on Instagram account @kemenkes_ri. The researchers observe Komik Sehat's stories delivered by the characters trying to present suggestions for implementing health protocols and healthy lifestyles during the Covid-19 pandemic. Pragmatics has an illocutionary act that can be used to see the speech in Komik Sehat, which contains a message of suggestions.

Illocutionary acts are speech acts or sentences from someone who takes action on the speech (Searle, 1969, p. 24). The illocutionary act theory can be used in speech acts that show suggestions. Licea-Haquet $(2019$, p. 45) explains that the illocutionary act is the intention of the action performed by the speaker through a certain sentence. Witek (2015) completes that illocutionary acts are performed to deliver the results of locutions in a conventional style, for example, making an agreement or statement. In Komik Sehat, illocutionary acts come from the utterances delivered by comic characters to convey the information or message.

Abdel-Raheem (2020) says that the pictorial illocutionary acts cannot stand alone without a headline or opinion from the author. Images contained in a comic always relate to the opinion of the comic artist who is represented through the comic character's utterance. In addition, comics also present a narrative or story. According to Norrick (2015), a narrative is a source of conversation to describe what is happening and represent expressive and directive conversation delivery. The comics used in this research describe the current situation of Covid-19. Therefore, research is needed to observe the process of delivering speech messages by comic characters, especially regarding recommendations for implementing health protocols and healthy lifestyles during the pandemic.

This research is conducted to prove the effectiveness of comics' usage as the media to deliver information to the wider communities in modest methods and can be used by government, institutions, or other organizations to deliver other important information. Based on the previous discussion, the problem in this research was the strategy of the Indonesian Ministry of Health in delivering suggestions for health protocols and healthy lifestyles implementation during Covid-19 through the character' utterances in Komik Sehat. So that, this research aims to explain the strategies used by the Indonesian Ministry of Health in delivering suggestions for health protocols and healthy lifestyles implementation through the characters' speech in Komik Sehat.

\section{Literature Review}

Searle $(1969$, p. 16) explains all language or communication activities always involve speech acts, such as producing symbols, signs, words, or sentences to create speech acts. Therefore, speech acts are used in this research to observe the results of symbols, signs, 
words, or sentences that contain recommendations for implementing health protocols and healthy lifestyles. The speech acts that will be used are illocutionary speech acts because the locutionary act expresses a statement through the meaning of words and sentences. Searle $(1969$, p.24) explains that the illocutionary speech act is the act of saying the utterance or sentence of a typical person who also acts he says. In addition, illocutionary acts also see the action with a distinctive power and can make the speaker do according to what he says, so illocutionary acts can also observe suitability between his speech and his actions. Illocutionary acts can also have a relationship with social functions.

Searle (1976, pp. 10-15) has proposed a revision of Austin's illocutionary opinion speech acts. There are 5 types of illocutionary speech acts: representative/assertive, directive, commissive expressive, and declarative. First, representative/assertive speech acts are speech acts that bind the speaker to something that happens, with the truth of the proposition expressed. For example, all assessment actions include accepting or rejecting, suggesting, boasting, complaining, claiming, reporting, and warning (Searle in Cruse, 2004, 356). Second, directive speech acts are speech acts that indicate an attempt by the speaker to make the interlocutor do something. For example, all actions include ordering, commanding, requesting, begging, advising, reminding, and recommending (Searle in Cruse, $2004,356)$. Third, commissive speech acts aim to commit the speaker to the action in the future. For example, all actions include promising, swearing, offering, and threatening suggestions (Searle in Cruse, 2004, 356). Fourth, expressive speech acts are acts that intend to express the psychological state determined in the sincerity condition about the state specified in the propositional content. For example, all actions include the act of saying thank you, congratulating, apologizing, forgiving, condolences, praising, and blaming (Searle in Cruse, 2004, 356). The last is declarative speech acts that guarantee the success of the speaker's action with the reality that occurs. The actions included in declarative speech acts include resigning, dismissing, divorcing, baptizing, excommunicating, naming, punishing, lifting, purifying, and others (Searle in Cruse, 2004, 356).

Previous research showed speech acts could be used as a method to achieve the desired communication goal, one of which is using memes (Grundlingh, 2018). Tsomou (2020) also completed that speech acts are the flexibility of communicative speech. Directive speech acts in an image on social media can be used for delivering information to have an impact that makes consumers curious and encourages consumers to share their messages (Ordenes et al., 2019). Ludwig and de Ruyter (2016) explain that speech acts in text-based conversations on social media that present more than just content. Meanwhile, Qi (2020) also adds that directive, expressive, and assertive speech acts in a video are the most common types of speech acts encountered in terms of mobilizing the specific segment to suit the speaker's demands. Previous research showed speech acts in an image or video are used as a purpose to communicate, deliver information, or more than just content. This is the trigger in this research to look deeper into the use of speech acts-especially illocutions-will focus on comics. Therefore, this research uses comics as the data to take a deeper look at speech acts.

Previous research related to comics or social media as a transmitter of information during Covid-19 has been performed. Kearns and Kearns (2020) have researched comics as a media that is familiar and accessible to a wide audience and can transcend language, knowledge, age, and cultural barriers. Comics are also considered to deliver the right facts to the right people, especially in Covid-19, which causes global chaos and misinformation (Kearns and Kearns, 2020). In addition to comics, social media is also used as a tool to deliver 
information or messages to wider communities. Hussein and Aljamili (2020) explain memes and caricatures related to Covid-19 shared on Jordanian social media sites have helped reduce the psychological impact of the pandemic on society. These two studies have triggered this research to observe the use of comics in social media to deliver information to wider communities, especially the information regarding suggestions for health protocols and healthy lifestyles implementation.

\section{Research Methods}

This research uses a mixed approach as a research methodology. A mixed approach is an investigative approach by collecting quantitative and qualitative data, integrating two forms of data, and using different designs may involve philosophical assumptions and theoretical frameworks (Creswell and Creswell, 2018). Quantitatively, all speech data that have passed the identification process will be grouped based on the types of speech acts. Then, grouped data will describe the percentage number occurrences of the largest types of speech acts. Numerical data consisting of the number of speech acts' types will be able to show the tendency of speech acts' types that shape the process of delivering suggestions for health protocols and healthy lifestyles implementation. Qualitatively, this research is conducted to explain data in speech form by using the illocutionary speech act' theory. This research use data from utterance contained in Komik Sehat. The Indonesian Ministry of Health published this comic on the Instagram account @kemenkes_ri. The data source used is 38 comic strips with 3 main criteria, data that show health protocols and healthy lifestyle suggestions, data showing complete utterances, and data from April 2020 to April 2021.
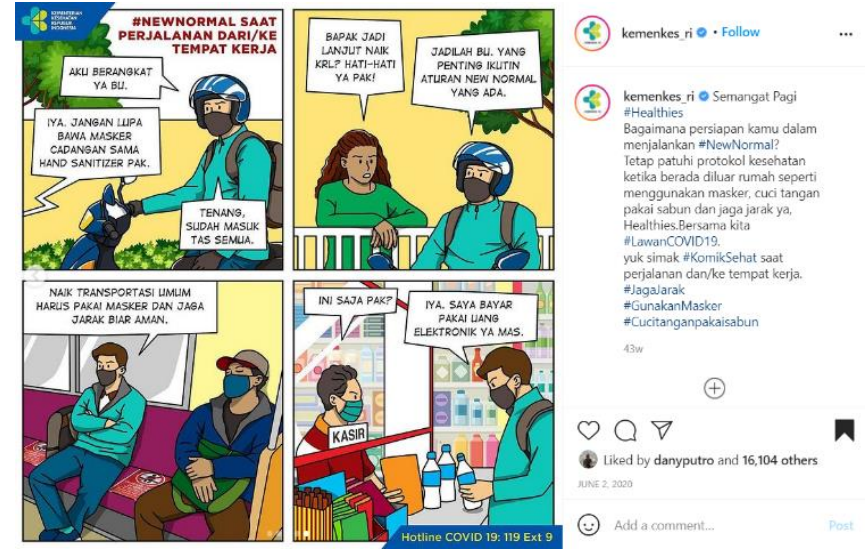

Figure 1. Komik Sehat published in the Indonesian Ministry of Health's official Instagram

\section{Results and Discussion}

This study only focuses on the illocutionary speech acts of the characters Komik Sehat. It aims to see a distinctive power generated by comic characters in their strategy to deliver important messages through utterances, especially messages regarding recommendations for implementing health protocols and healthy lifestyles. Furthermore, this distinctive power is expected to recomend for the community in implementing health protocols and healthy lifestyles during Covid-19. Discussion is explained in two parts, analysis of speech acts that contain the elements of health protocols implementation and analysis of speech acts that contain elements of healthy lifestyle implementation. After classifying and identifying the data, the number of illocutionary speech acts found in Healthy Comics is 212 utterances consisting of three types of speech acts, 19 expressive, 82 assertive, and 111 directive. The following table shows the number of illocutionary speech acts in Komik Sehat. 


\begin{tabular}{|l|c|c|}
\hline \multicolumn{1}{|c|}{ Illocutionary Speech Act } & Total Utterances & Percentage \\
\hline Expressive & 19 & $8,96 \%$ \\
\hline Assertive & 82 & $38,68 \%$ \\
\hline Directive Total & 111 & $52,36 \%$ \\
\hline \multicolumn{2}{|c|}{ Total } & $\mathbf{1 0 0 \%}$ \\
\hline
\end{tabular}

Table 1. Illocutionary Speech Act in Komik Sehat

\subsection{Utterances Regarding Suggestion for Health Protocols Implementation}

The first part explains the utterances of comic characters that contain illocutionary speech acts related to suggestions for implementing health protocols during Covid-19. Indonesian Ministry of Health $(2020,25)$ said the health protocols implementation must be carried out strictly in every activity as an effort to prevent transmission of Covid-19 cases. Searle (1976, pp. 10-15) has explained that there are five types of speech acts, but in Komik Sehat, only three types of illocutionary speech acts are found, expressive, assertive, and directive. Table 1 shows expressive speech acts usage in comics is only $8.96 \%$. Meanwhile, directive speech acts are the most frequently used speech acts in Komik Sehat with $52.36 \%$ occurrences, and assertive speech acts are the second-highest speech acts with $38.68 \%$ occurrences.

\begin{tabular}{|l|c|c|c|}
\hline \multirow{2}{*}{ Illocutionary Speech Act } & \multicolumn{3}{|c|}{ Total Utterances } \\
\cline { 2 - 4 } & $\begin{array}{c}\text { Related to Health } \\
\text { Protocols }\end{array}$ & $\begin{array}{c}\text { Not Related to } \\
\text { Health Protocols }\end{array}$ & Total \\
\hline Expressive & 0 & 19 & 19 \\
\hline Assertive & 11 & 71 & 82 \\
\hline Directive & 75 & 36 & 111 \\
\hline Total & $\mathbf{8 6}$ & $\mathbf{1 2 6}$ & $\mathbf{2 1 2}$ \\
\hline
\end{tabular}

Table 2. Total Utterances Related to Health Protocols Implementation

Table 2 has presented the overall results of the utterances in comics related to the delivery of messages suggesting health protocols implementation. Based on table 2, expressive illocutionary speech acts do not show utterances that contain messages suggesting health protocols implementation during Covid-19. In the 19 utterances that include expressive speech acts, all of them only deliver expressions of the characters. Therefore, Table 3 can show expressive utterances without the elements of health protocols implementation. In addition, Table 3 will also show examples of assertive and directive speech acts.

In Table 3, the utterances that show expressive illocutionary speech acts are speech I.3. The utterance has the expressive power to warn the child and apologize to the female character with the yellow headscarf. Of course, the utterance does not indicate health protocols implementation. Meanwhile, based on Table 2, there are 11 assertive speech acts that indicate the element of implementing health protocols. One example of assertive speech acts that can be found is WK.1, which is found in Table 3. WK.1 utterances show an act of acceptance by the female character with the yellow headscarf against the utterance spoken by the previous character regarding the correct use of masks. However, the assertive illocutionary speech act contained in Komik Sehat-as in the example of WK.1 speech-is not included as a message of suggestion because the assertive illocutionary speech act does not show a special power or action to invite other characters or comic readers to the health protocols implementation during Covid-19. Then, the number of assertive speech acts that 
contain elements of health protocols also tends to be low, even much lower than assertive speech acts that do not contain elements of implementing health protocols, namely 71 utterances. However, the 11 assertive speech acts still reflect the suggestions of health protocols.

\begin{tabular}{|c|c|c|c|}
\hline No. & Figure & Utterances In Bahasa & Utterances In English \\
\hline 1. & 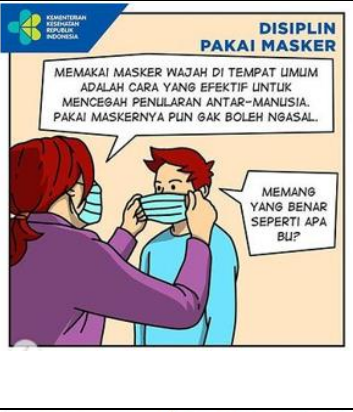 & $\begin{array}{l}\text { I.1: "Memakai masker wajah } \\
\text { di tempat umum adalah cara } \\
\text { yang efektif untuk mencegah } \\
\text { penularan antar-manusia } \\
\text { pakai maskernya pun gak } \\
\text { boleh ngasal." } \\
\text { A.1: "Memang yang benar } \\
\text { seperti apa Bu?" }\end{array}$ & $\begin{array}{l}\text { I.1: "Wearing a mask in } \\
\text { public is an effective way to } \\
\text { prevent human-to-human } \\
\text { infection, so don't wear the } \\
\text { mask carelessly." } \\
\text { A.1: "So, how is it mom?" }\end{array}$ \\
\hline 2. & & $\begin{array}{l}\text { I.2: "Masker harus menutupi } \\
\text { hidung sampai mulut dan } \\
\text { dagu. Harus pas dengan } \\
\text { wajah dan jangan longgar. } \\
\text { Jika hal itu terjadi, maka sia- } \\
\text { sia lah kegunaan masker } \\
\text { yang kamu pakai." }\end{array}$ & $\begin{array}{l}\text { I.2: "The mask should cover } \\
\text { the nose to the mouth and } \\
\text { chin. It should fit perfectly } \\
\text { and not be loose. If that } \\
\text { happens, then the use of the } \\
\text { mask you wear is useless." }\end{array}$ \\
\hline 3. & 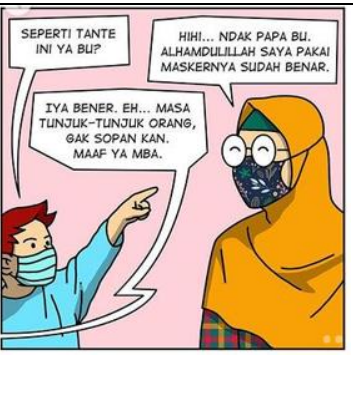 & $\begin{array}{l}\text { A.2: "Seperti tante ini ya Bu?" } \\
\text { I.3: "Iya bener. Eh... masa } \\
\text { tunjuk-tunjuk orang, gak } \\
\text { sopan kan. Maaf ya Mba." } \\
\text { WK.1: "Hihi... ndak papa Bu. } \\
\text { Alhamdulillah saya pakai } \\
\text { maskernya sudah benar." }\end{array}$ & $\begin{array}{l}\text { A.2: "is it like she did, mom?" } \\
\text { I.3: "Yeah, you're right. Hei... } \\
\text { it's unnecessary to point at } \\
\text { people, it's impolite. Sorry, } \\
\text { ma'am." } \\
\text { WK.1: "Hihi... it's okay, } \\
\text { ma'am. Alhamdulillah, I wear } \\
\text { the mask correctly." }\end{array}$ \\
\hline 4. & & $\begin{array}{l}\text { I.4: "Gantilah masker jika } \\
\text { rusak, kotor, atau basah. } \\
\text { Lepas kaitan masker dari } \\
\text { telinga atau ikatan masker, } \\
\text { pastikan tidak memegang } \\
\text { bagian depan masker." } \\
\text { A.3: "Ayo, jangan kendor! } \\
\text { Disiplin pakai masker." }\end{array}$ & $\begin{array}{l}\text { I.4: "Replace the mask if it is } \\
\text { defact, dirty, or wet. Unhook } \\
\text { the mask from the ears or } \\
\text { the ties of the mask, make } \\
\text { sure don't touch the } \\
\text { surface." } \\
\text { A.3: "Let's use our mask in a } \\
\text { proper way and be dicipline!" }\end{array}$ \\
\hline
\end{tabular}

Notes: $A=A n a k, I=l b u, W K=$ Wanita berkerudung kuning.

Table 3. Expressive, Assertive, and Directive Speech Acts Related to Health Protocols Implementation

Table 2 has also shown the results of directive speech acts that contain elements of implementing health protocols. Meanwhile, the number of directive speech acts related to health protocols implementation during Covid-19 was 75 utterances, and those unrelated to health protocols were only 36 utterances. The data shows that directive speech acts are illocutionary speech acts with the highest level of use to show health protocols implementation compared to other types of illocutionary speech acts. Meanwhile, Table 3 also shows examples of utterances representing directive speech acts related to health 
protocols implementation; they are I.1, I.2, I.4, and A.3. In Table 3, the number of directive speech acts also has the most frequent occurrences. In addition, all the directive speech acts in the comics also contain messages that suggest health protocols implementation. The directive's speech shows that there is a special power spoken by the character to advise (I.1, I.2, and I.4) and remind (A.3) the interlocutor regarding the proper use of masks during Covid-19. In addition, the act of advising and reminding can also influence the reader to follow the advice given by the comic characters. Based on this, the four directive utterances can represent utterances that show suggestions for the health protocols implementation through utterances that describe the actions of advising and reminding.

Table 4 shows illocutionary speech acts related to health protocols are $40.57 \%$. The directive speech act is the most widely used illocutionary speech act in Komik Sehat. From the 111 directive speech acts, $67.57 \%$ are related to health protocols implementation. Then, based on 82 assertive speech acts, $13.41 \%$ show health protocols implementation. Meanwhile, 19 expressive speech acts in comics did not show any relation to health protocols implementation. Thus, it can be seen that directive speech acts are the most widely used illocutionary speech acts in the process of delivering messages related to health protocols. These directive speech acts are used to give advice and influence interlocutors in comics and comic readers in implementing health protocols. In line with Searle (1976), directive speech acts indicate an attempt by the speaker to get the interlocutor to do something. Therefore, the purpose of the Indonesian Ministry of Health to educate the communities-especially Instagram users-about the importance of health protocols implementation can be represented by comics' usage.

\begin{tabular}{|l|c|}
\hline \multicolumn{1}{|c|}{ Illocutionary Speech Act } & Percentage \\
\hline Expressive & $0 \%$ \\
\hline Assertive & $13.41 \%$ \\
\hline Directive & $67.57 \%$ \\
\hline Total & $\mathbf{4 0 . 5 7 \% *}$ \\
\hline
\end{tabular}

Notes:

* Percentage calculation was obtained from total illocutionary speech acts related to health protocols $(N=86)$ compared to the total speech acts $(\Sigma N=212)$.

Table 4. Percentage Utterances Related to Health Protocols Implementation

Based on the analysis, Komik Sehat uses many directives speech acts as a strategy for delivering messages to perform recommended messages according to the characters in the comics. However, what needs to be noted is the use of illocutionary speech acts as a whole which shows that the process of delivering messages recommending health protocols implementation tends to be low. It can be a special concern for institutions who want to deliver an important message through comics by increasing the number of speech acts that reflect this important message. Komik Sehat has tried to deliver messages suggesting health protocols implementation with directive speech acts. Based on that case, the strategy of delivering messages through directive speech acts in Komik Sehat should be the media for delivering health protocol suggestions, especially people who use Instagram. However, based on data that has been obtained, the Indonesian Ministry of Health can further increase the use of utterances that have special power to their interlocutor/readers to do things that are exemplified, such as increasing the use of directive speech acts. 


\subsection{Utterances Regarding the Suggestion for Healthy Lifestyles Implementation}

A healthy lifestyle is an important aspect that must be concerned while Covid-19 can easily attack human health. The Indonesian Ministry of Health $(2020,110)$ has said that one of the methods that can be used as a self-preventive step to deal with Covid-19 is increasing body resistance by implementing a clean and healthy lifestyle such as consuming balanced nutrition, doing physical activity for at least 30 minutes a day, having adequate rest, and using the traditional health. The Ministry of Health of the Republic of Indonesia also tries to provide insight regarding a healthy lifestyle through Komik Sehat. Table 5 presents the number of utterances in comics-related to healthy lifestyle implementation.

Based on the three types of speech acts found in Table 5, only the directive speech acts show the delivery of the messages regarding the suggestion of healthy lifestyle implementation. The utterances consist of 14 utterances. Meanwhile, 19 expressive speech acts and 82 assertive speech acts did not show any message of advice for a healthy lifestyle during Covid-19. In order to show the form of directive speech that contains a message suggesting healthy lifestyle implementation, Table 6 shows an example.

\begin{tabular}{|l|c|c|c|}
\hline \multirow{2}{*}{ Illocutionary Speech Act } & \multicolumn{3}{|c|}{ Total Utterances } \\
\cline { 2 - 4 } & $\begin{array}{c}\text { Related to Healthy } \\
\text { Lifestyle }\end{array}$ & $\begin{array}{c}\text { Not Related to } \\
\text { Healthy Lifestyle }\end{array}$ & Total \\
\hline Expressive & 0 & 19 & 19 \\
\hline Assertive & 0 & 82 & 82 \\
\hline Directive & 14 & 97 & 111 \\
\hline Total & $\mathbf{1 4}$ & $\mathbf{1 9 8}$ & $\mathbf{2 1 2}$ \\
\hline
\end{tabular}

Table 5. Total Utterances Related to Healthy Lifestyle Implementation

\begin{tabular}{|c|c|c|c|}
\hline No. & Figure & Utterances In Bahasa & Utterances In English \\
\hline 1. & 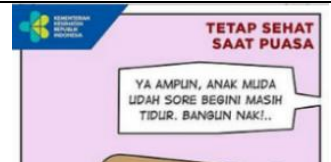 & $\begin{array}{l}\text { I.1: "Ya ampun, anak muda } \\
\text { udah sore begini masih } \\
\text { tidur, bangun Nak!" }\end{array}$ & $\begin{array}{l}\text { I.1: "Oh my goodness, why } \\
\text { you are still sleeping in this } \\
\text { afternoon, wake up son!" }\end{array}$ \\
\hline 2. & & $\begin{array}{l}\text { A.1: "Habisnya aku lemes, } \\
\text { Bu." } \\
\text { I.2: "Kamu nggak nurut } \\
\text { sama Ibu, sih! Kita harus } \\
\text { tetap jaga asupan gizi dan } \\
\text { pola hidup sehat selama } \\
\text { berpuasa Ihoo." }\end{array}$ & $\begin{array}{l}\text { A.1: "I'm not feeling good, } \\
\text { ma'am." } \\
\text { I.2: "I told you so, but you } \\
\text { didn't listen to me! We need } \\
\text { to continue to maintain } \\
\text { nutritional intake and a } \\
\text { healthy lifestyle during } \\
\text { fasting." }\end{array}$ \\
\hline 3. & 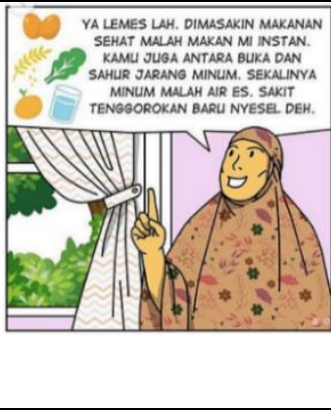 & $\begin{array}{l}\text { I.3: "Ya lemes lah. } \\
\text { Dimasakin makanan sehat } \\
\text { malah makan mi instan. } \\
\text { Kamu juga antara buka } \\
\text { dan sahur jarang minum, } \\
\text { sekalinya minum malah air } \\
\text { es, sakit tenggorokan baru } \\
\text { nyesel deh." }\end{array}$ & $\begin{array}{l}\text { I.3: "Of course, you feel bad. } \\
\text { You choose instant noodle } \\
\text { rather than healthy food i } \\
\text { cooked. You also rarely drink } \\
\text { between iftar and sahur, } \\
\text { once you drink iced water, } \\
\text { you just have a sore throat." }\end{array}$ \\
\hline
\end{tabular}




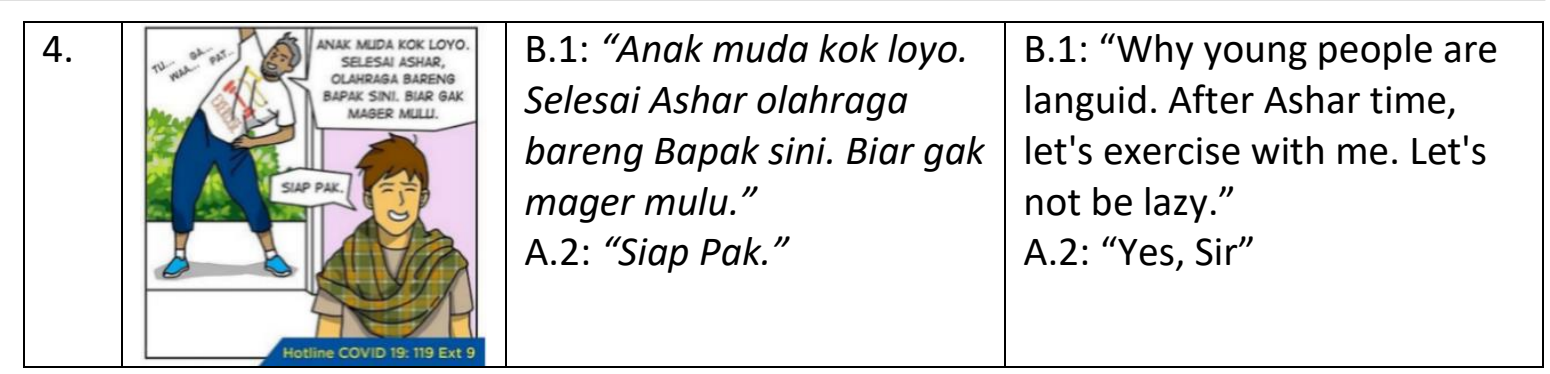

Notes: I=Ibu, $A=A n a k, B=B a p a k$.

Table 6. Directive Speech Acts Related to Healthy Lifestyle Implementation

Table 6 shows 3 utterances that include directive speech acts related to healthy lifestyle implementation during Covid-19, 1.2, 1.3, and B.1. In 1.2, the utterance is included in the directive advising speech act because the utterance delivered by the mother character shows the act of giving advice or suggestions to her interlocutor-the child's character-to maintain nutritional intake and a healthy lifestyle during fasting at a pandemic. In those utterances, the mother advises maintaining health because it is triggered by the speech of the child's character in A.1. Meanwhile, 1.3 is also the utterance included in the directive advising speech act. That is because the utterance delivered by the mother has a special power to deliver messages to her son regarding healthy foods that must be eaten during fasting and advise her son not to drink and eat carelessly. Furthermore, utterances that include directive speech acts related to a healthy lifestyle are B.1. In B.1, the father has a special power or action to ask his son to join him in exercising so that a healthy lifestyle is maintained and the body is not weak.

\begin{tabular}{|l|c|}
\hline \multicolumn{1}{|c|}{ Illocutionary Speech Act } & Percentage \\
\hline Expressive & $0.00 \%$ \\
\hline Assertive & $0.00 \%$ \\
\hline Directive & $12.61 \%$ \\
\hline Total & $6.6 \% *$ \\
\hline
\end{tabular}

Notes:

* Percentage calculation is obtained from total speech related to a healthy lifestyle $(\mathrm{N}=14)$ compared to total speech $(\Sigma \mathrm{N}=212)$.

Tabel 7. Percentage Utterances Related to Healthy Lifestyles Implementation

The three utterances that have been discussed previously have shown the strategy of using directive speech acts as a way to deliver messages that suggest healthy lifestyle implementation. However, from the 212 utterances, only 14 utterances show healthy lifestyle implementation. This can lead to a lack of public attention-especially people who use Instagram - to implement a healthy lifestyle during Covid-19. Table 7 shows the percentage utterances usage deliver messages suggesting healthy lifestyle implementation. Overall, there are only $6.6 \%$ of utterances deliver the suggested message. Meanwhile, the utterance that delivers a message is only found in directive speech acts of $12.61 \%$ among other directive speech acts. It has shown that delivering messages suggesting healthy lifestyle implementation by the Indonesian Ministry of Health through Komik Sehat on Instagram is less effective. The lack of utterances that show suggested messages healthy lifestyle implementation is cause ineffectiveness of delivering these messages. 


\section{Conclusions}

This research examines the strategy for delivering messages as a suggestion for health protocols and healthy lifestyles implementation during Covid-19 through Komik Sehat by the Indonesian Ministry of Health. This research mainly explains the strategy of delivering messages through the utterances in comics. The data used in this research came from Komik Sehat uploaded by the Indonesian Ministry of Health on Instagram. In this research, the utterances examined are utterances included in the type of illocutionary speech act. Based on data processing, 212 utterances in the comics are illocutionary speech acts consisting of 19 expressive speech acts, 82 assertive speech acts, and 111 directive speech acts.

Based on the analysis, this research's first finding is the character utterances shown in the messages' delivery suggesting health protocols implementation. The strategy of delivering messages on the health protocols implementation in Komik Sehat can already be one of the media for delivering important messages by using directive speech acts. It is based on the percentage of directive speech acts related to the suggestion for health protocols implementation to get a fairly high result, $67.57 \%$ of the 111 directive speech acts contained in comics. In addition, another type of speech act that shows elements of implementing health protocols is assertive speech acts, with a percentage of $13.41 \%$ of 82 utterances. In this finding, important aspects need to be underlined; the percentage of overall speech that shows the suggested elements of implementing health protocols tends to be low, $40.57 \%$ of the 212 utterances. Based on this, the Indonesian Ministry of Health can increase utterances usage that has a special ability to interlocutor/readers to do something shown in comics, such as increasing the use of directive speech acts reflect suggestion messages.

The second finding is character utterances that show the delivery of messages suggesting healthy lifestyle implementation. The analysis results show that there are fewer strategies for delivering messages suggesting healthy lifestyle implementation in Komik Sehat. Based on the 212 illocutionary speech acts, only directive illocutionary speech acts suggest the implementation of a healty lifestyle. Meanwhile, the directive speech acts that delivered the message were $12.61 \%$ of the 111 directive speech acts. Overall, $6.6 \%$ of the 212 utterances delivered messages suggesting healthy lifestyle implementation. These results indicate the strategy of the Indonesian Ministry of Health in using comics to deliver messages suggesting healthy lifestyle implementation through utterance in comics is less effective. This can lead to a lack of public attention to healthy lifestyle implementation during Covid-19.

In conclusion, the strategy of delivering messages suggesting health protocols and healthy lifestyles implementation through utterance in comics is less effective. It is based on the overall data processing, which indicates a low percentage, $40.57 \%$ of utterances that deliver suggestions for health protocols and $6.6 \%$ of utterances that deliver suggestions for healthy lifestyles. This research is conducted to prove the effectiveness of Komik Sehat as the media for delivering messages suggesting health protocols and healthy lifestyles implementation during Covid-19. However, this research has limitations with the analysis of utterances in comics. Future research needs to conduct a broader analysis on Komik Sehat from the Indonesian Ministry of Health, especially in the analysis of visual meaning shows the delivery of the suggested messages as well as an analysis of the relevance of utterance and visual meaning in comics that realize the delivery of the suggested messages. 


\section{References}

Abdel-Raheem, A. (2020). "Do political cartoons and illustrations have their own specialized forms for warnings, threats, and the like? Speech acts in the nonverbal mode". Social Semiotics, 1-34.

Austin, J. (1962). How to Do Things with Words. London: Oxford University Press.

Creswell, J. W., and Creswell, J. D. (2018). Research design: Qualitative, quantitative, and mixed methods approach. 5th edition. California: SAGE publications.

Cohn, N. (2012). Comics, Linguistics, and Visual Language: The Past and Future of a Field. In Bramlett, F., (Eds.), (2012). Linguistics and the Study of Comics (pp. 92-118). New York: Palgrave Macmillan.

Cruse, D. A. (2004). Meaning in Language: An Introduction to Semantics and Pragmatics. New York: Oxford University Press.

Eisner, W. (1985). Comics \& Sequential Art. Florida: Poorhouse Press.

Grundlingh, L. (2018), Memes as speech acts. Social Semiotics, 28(2), 147-168.

Hussein, A. T., \& Aljamili, L. N. (2020) COVID-19 humor in Jordanian social media: A sociosemiotic approach. Heliyon, e05696.

Indonesian Ministry of Health (2020), Pedoman Pencegahan dan Pengendalian Coronavirus Disease (Covid-19) Revisi Ke-5. Jakarta: Kemenkes RI.

Kearns, C., \& Kearns, N. (2020). The role of comics in public health communication during the COVID-19 pandemic. Journal of visual communication in medicine, 43(3), 139-149.

Kemp, S. (2021). Digital 2021: Indonesia. Retrieved Septermber $20^{\text {th }} 2021$ from https://datareportal.com/reports/digital-2021-indonesia

Licea-Haquet, G. L., Velásquez-Upegui, E. P., Holtgraves, T., \& Giordano, M. (2019). Speech act recognition in Spanish speakers. Journal of Pragmatics, 141, 44-56.

Ludwig, S., \& de Ruyter, K. (2016). Decoding social media speak: developing a speech act theory research agenda, Journal of Consumer Marketing, 33(2), 124-134.

Norrick, N. R. (2015). Narrative illocutionary acts direct and indirect, Journal of Pragmatics, 86, 94-99.

Ordenes, F. V. et al. (2019). Cutting through content clutter: How speech and image acts drive consumer sharing of social media brand messages, Journal of Consumer Research, 45(5), 988-1012.

Searle, J. R. (1969). Speech Acts: An Essay in the Philosophy of Language. New York: Cambridge University Press.

Searle, J. R. (1976). A classification of illocutionary acts. Language in society, 1-23.

Qi, Y. (2020). The language of terror: exploring speech acts in official English-language ISIS videos. Small Wars \& Insurgencies, 31(6), 1196-1241.

Witek, M. (2015). Linguistic under determinacy: A view from speech act theory. Journal of Pragmatics, 76, 15-29.

Zappavigna, M. (2016) "Social media photography: construing subjectivity in Instagram images. Visual Communication, 15(3), 271-292. 